\title{
A német LK II és a svéd Strv m/21 típusú harckocsik, valamint magyar vonatkozásaik m.resz
}

\section{CSAK EGY ÁRTALMATLAN NÉMET TRAKTOR... - AZ LK II SvÉDORSZÁGBAN}

Bár a svédek utolsó hagyományos háborújukat 1814-ben vívták és végül mindkét világháborúban semlegesek maradtak, a XX. század során végig komoly hangsúlyt fektettek arra, hogy lehetőségeikhez mérten a legmodernebb, legfejlettebb - általában német eredetű - fegyverekkel szereljék fel hadseregüket arra az esetre, ha semlegességüket vagy szuverenitásukat mégis fegyveresen kellene megvédeniük. Nem jelentett ez alól kivételt az első világháború egyik „csodafegyvere”, a tank, vagyis harckocsi sem.

A svéd hadsereg első ízben 1918 elején tanulmányozhatta ezt az új harceszközt egy küldöttsége útján Berlinben, ahol a németek bemutattak nekik egy általuk elfogott brit Mark IV-es harckocsit. Nem sokkal a háború után, 1919 nyarán a svédek tárgyalásokat is kezdeményeztek a brit kormánnyal, hogy a hadseregük részére Whippet harckocsikat vásárolhassanak, de a kor csúcstechnológiájának számító harceszközökért a britek olyan magas összeget kértek, amit a svéd hadsereg akkor nem engedhetett meg magának. Így a svédek kénytelenek voltak más, megfizethetőbb változat után nézni, ha nem akartak lemaradni a hadászat-harcászat világszínvonaltól. A - nem kifejezetten törvényes - megoldást végül a háborús vesztes Németországban találták meg.

1921 januárjában a svéd parlament egy igen nagy összeget, több, mint másfél millió svéd koronát szavazott meg a hadsereg fejlesztéséhez végzendő kísérletek és „technikai felszerelések" beszerzéséhez, ami így a korábban, a brit harckocsik vásárlásánál még hiányzó anyagi hátteret is biztosította már.

Februárban a $\mathrm{KAAD}^{8}$ utasította a berlini svéd katonai attasét, hogy vizsgálja meg, hogy a világháborúból megma-

\section{1. ábra. A svéd hadsereg küldöttsége 1918 januárjában megszemléli Németországban a császári német hadsereg által zsákmányolt egyik brit Mark IV-es harckocsit}

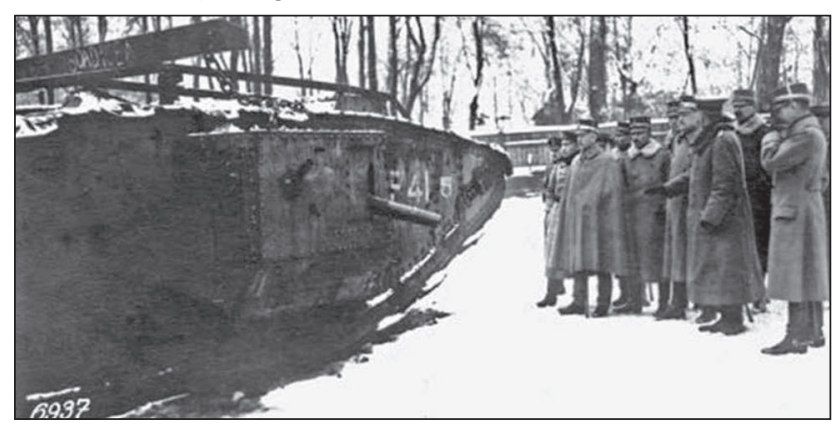

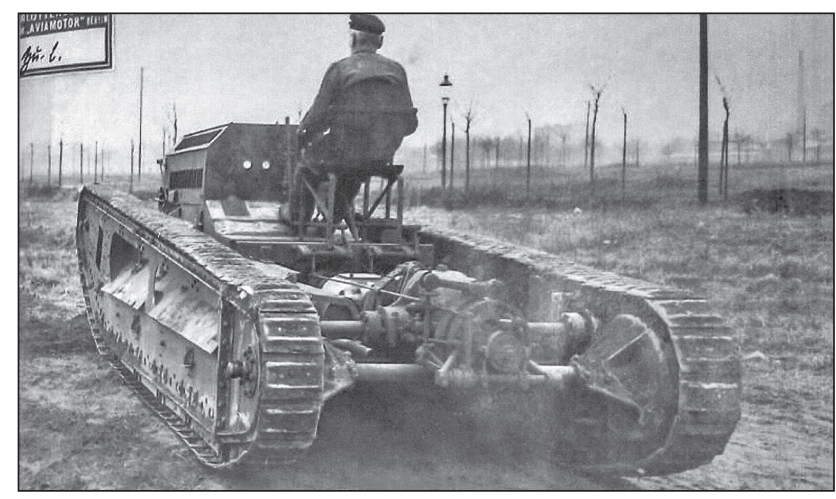

12. ábra. A Steffen \& Heymann által felajánlott „lánctalpas nehéz vontató" fényképe, amelyet az 1921. márciusi ajánlattételükhöz is csatoltak. A képen könnyen felismerhető a páncélborítás és felépítmény nélküli LK II alváza

radt, feleslegessé vált német katonai felszerelések vásárlása érdekében van-e lehetőség tárgyalások kezdeményezésére Németországban. Az egyik ilyen lehetséges szerződő fél egy kisebb, Steffen \& Heymann GmbH nevű német cég lett volna, ami feltehetően közvetítőként vett részt a svédek és nagyobb német vállalatok, fegyvergyárak közötti alkudozásokban. A Steffen \& Heymann által felajánlott fegyverek, tüzérségi- és légvédelmi lövegek, illetve gépesített tüzérségi vontatók között érdekes módon „új típusú lánctalpas nehézvontató"-ként ${ }^{9}$ ott szerepelt az LK II könnyű harckocsi páncéllemezek nélküli alváza is. Ez iránt - érthető módon - a svédek élénk érdeklődést mutattak. Mikor a Steffen \& Heymann-nal folyó tárgyalások 1921 júliusában újból felélénkültek, a német cég a birtokában lévő 15 darab ilyen „nehéz vontatóért” (valójában komplett, fegyverzet nélküli LK II harckocsiért) darabonként 445000 német márkát kért.

A Steffen \& Heymann szerencsétlenségére azonban ekkorra a svédek egy ennél is kedvezőbb ajánlatot kaptak egy másik német cégtől, a berlini Wilhelm Ugé GmbH mérnöki irodától, amely a birtokában lévő 10 darab LK II-est még kedvezőbb áron ajánlotta fel nekik. ${ }^{10} \mathrm{~A}$ hónap végén - V. Gusztáv svéd király tudomásával és hallgatólagos jóváhagyásával - nyélbe is ütötték az üzletet, amelynek értelmében a szemrevételezést végző svéd tiszt magánszemélyként vásárolta meg a Wilhelm Ugé GmbH-tól a 10 darab „nehézvontatót”. A szerződésbe nem került semmilyen, a svéd érdekeltségre vagy hadügyre vonatkozó említés sem, amire természetesen azért volt szükség, mert a versailles-i békeszerződés értelmében ezeknek a harckocsiknak ekkorra már nem is lett volna szabad létezniük. Később a hivatalos ürügy, amiért ezeket a járműveket

ORCID: 0000-0002-8352-3645 

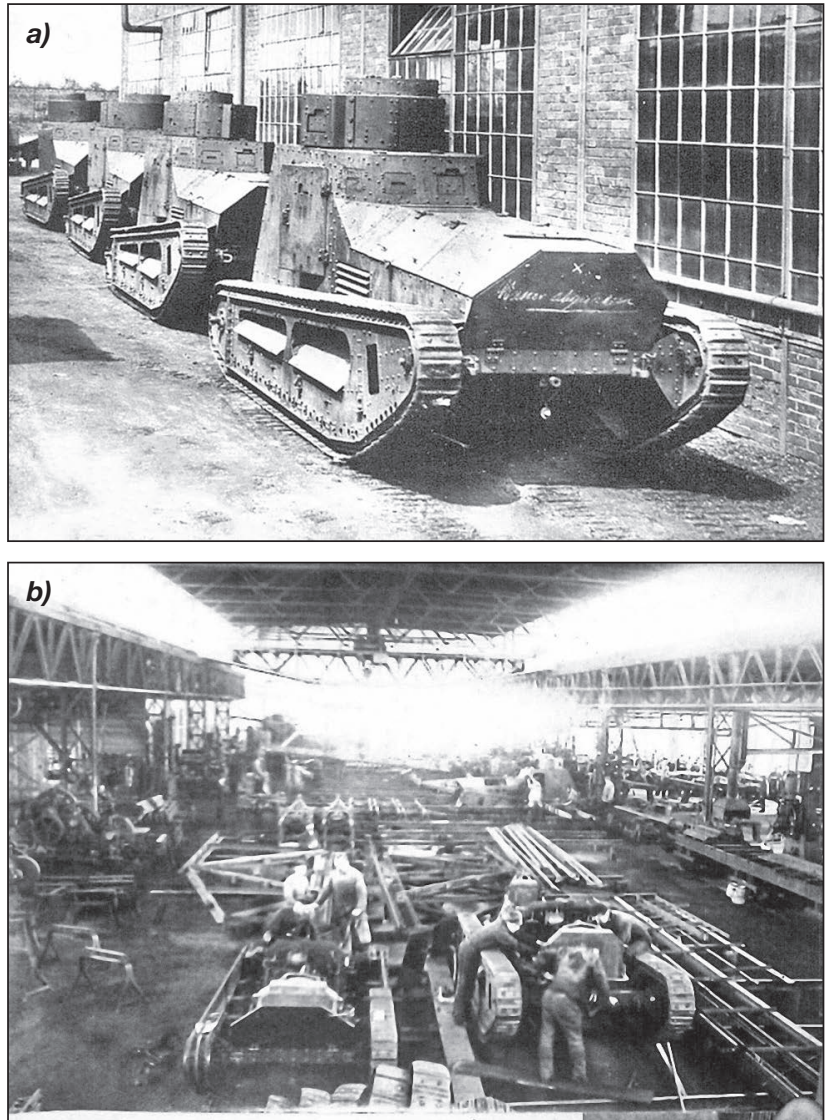

13. ábra. A Steffen \& Heymann által 1921 júliusában a svédeknek küldött tájékoztató levélhez csatolt fényképek, amelyeken az eladásra kínált LK II-k közül négy példány (a), valamint további példányok (b) Németországban zajló összeszerelése látható

„gyártották"11 az volt, hogy a királyi családot lettek volna hivatottak védelmezni egy feltételezett svédországi kommunista forradalom során.

A Németországban gyártott LK II-es alkatrészeket szétszerelt állapotban, titokban, „kazán”, illetve „mezőgazdasági gép alkatrészei"-ként kezdték el 1921 szeptemberétől kisebb, nem feltűnő szállítmányokra bontva hajón Svédországba szállítani, ahol fokozatosan hozzákezdtek az öszszeszerelésükhöz. Az első próbadarabot a Stockholms

14. ábra. Az egyik első, Svédországban összeszerelt LK II-es, 1922 tavaszán

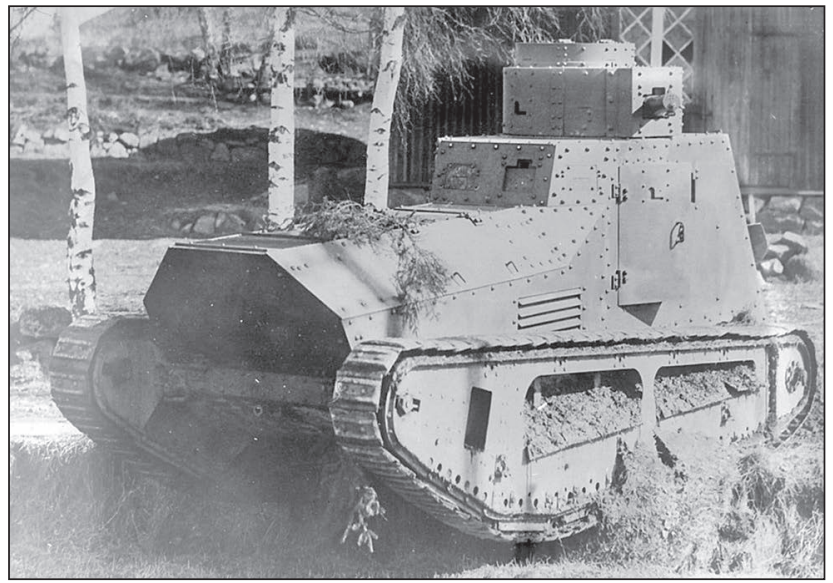

Tygstation állami hadianyaggyárban, a további darabokat pedig a stockholmi kikötő egyik raktárában állították össze a Wilhelm Ugé GmbH által biztosított német szakértő felügyeletével. Mindezekért cserébe a Wilhelm Ugé cég öszszesen 2500000 (vagyis harckocsinként 250 000) német márkát kapott, ami - a svédek szempontjából - még az egyéb járulékos költségeket is hozzászámolva, a német márka akkoriban zajló folyamatos elértéktelenedése miatt határozottan jó üzletnek bizonyult. Mindenesetre a páncélburkolat lemezeit érintő különböző problémák, és a lassan beérkező alkatrészek miatt az utolsó kész harckocsik átadása végül 1922 nyaráig húzódott el.

\section{A StridsVaGn m/21, SvÉdorSZÁG ELSŐ HARCKOCSIJA}

A Svédországban összeszerelt LK II-esek az Strv m/21 nevet ${ }^{12}$ kapták a svéd hadsereg kötelékében. Az 1-től 10-ig számozott harcjárműveket a Stockholmban állomásozó elit Svea Livgarde gyalogezredhez osztották be 1922. augusztus 11-én, amely dátumot később a svéd páncélos fegyvernem megalakulásának időpontjaként tartottak nyilván. A svéd hadsereg tisztjei az elkövetkező években e típus, és egy akkoriban vásárolt francia Renault FT könnyű harcko$\mathrm{csi}^{13}$ segítségével kezdték kikísérletezni, hogy hogyan, s miként is lehetne alkalmazni ezt az akkor még mindig nagyon is újnak számító harceszközt a skandináv viszonyok között. Az 1920-as évek közepéig az Strv m/21-esek számos, csak harckocsikat felvonultató vagy más haderőnemekkel közös hadgyakorlaton vettek részt. Egy darab Strv m/21-est kiképzési célból parancsnoki harckocsivá alakítottak át, vagyis rádió adó-vevővel és hozzá tartozó antennával is elláttak.

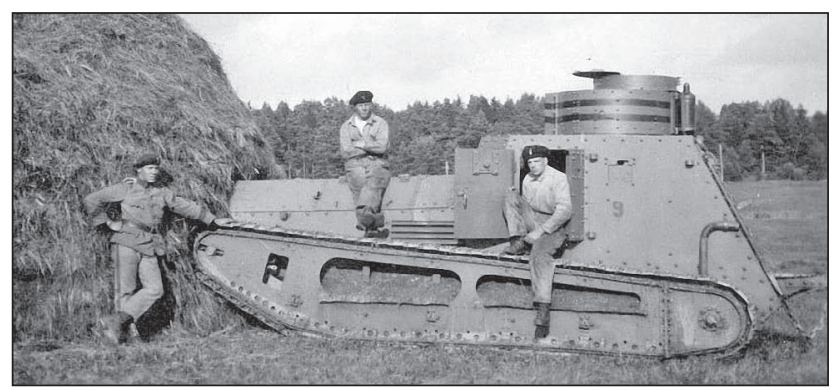

15. ábra. Egy fegyverzet nélküli Strv m/21-es és személyzete

16. ábra. A svédek által vásárolt egyetlen francia Renault FT, becenevén „Putte” (a képen nyolc óra irányba néző toronnyal)

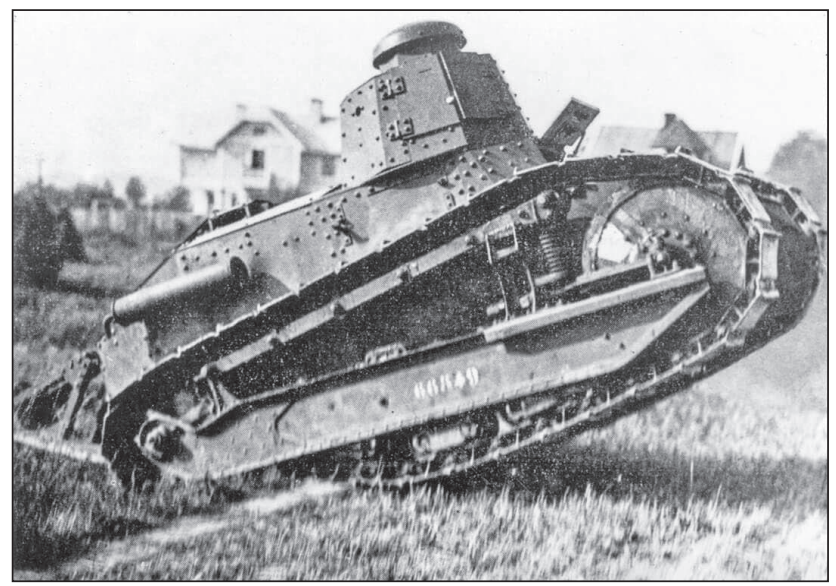




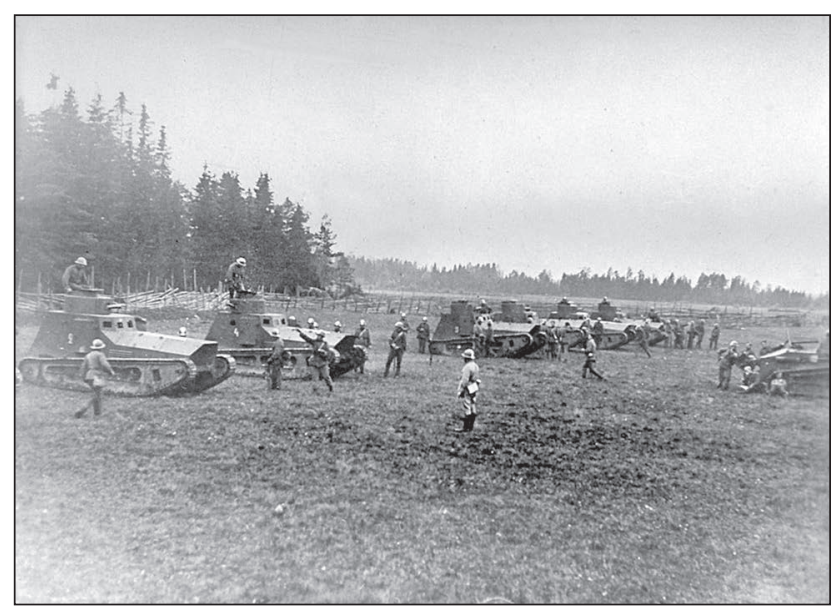

17. ábra. Svéd páncélosok egy gyalogsággal közös hadgyakorlaton. A kép jobb szélén a „Putte” becenevű svéd FT is látható

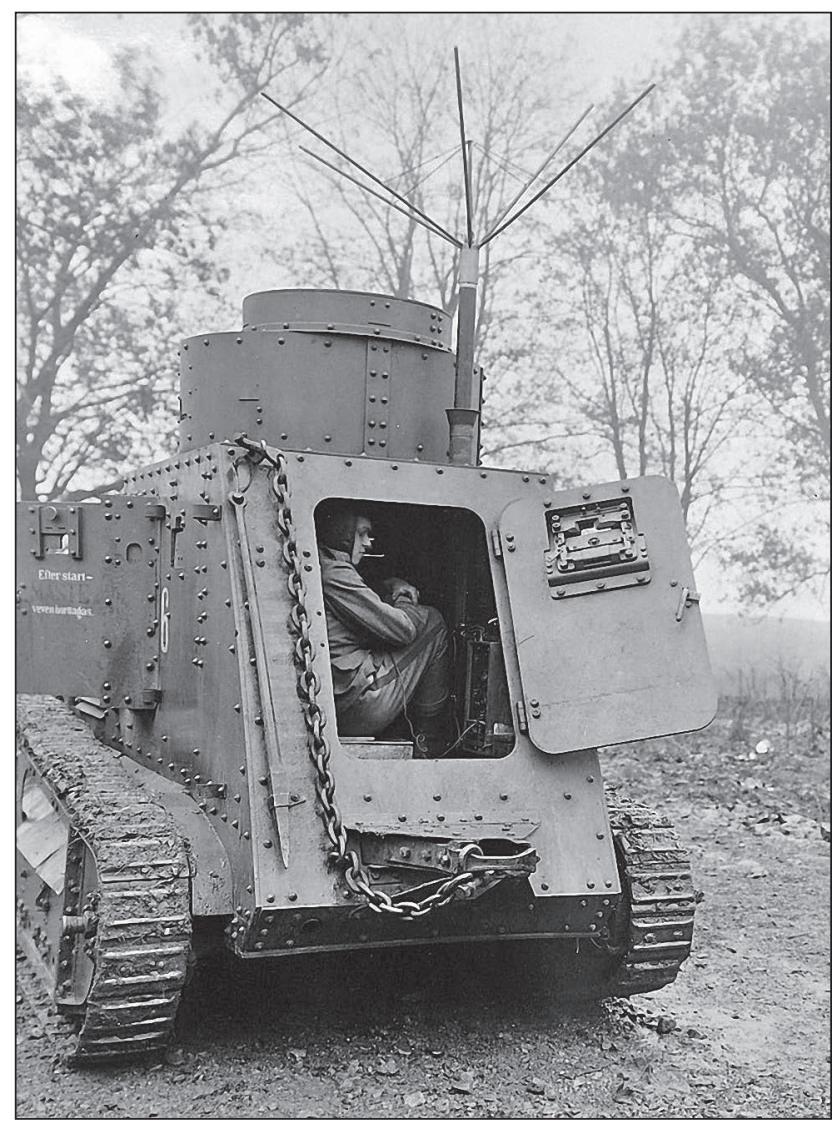

18. ábra. A rádióval is felszerelt parancsnoki Strv $\mathrm{m} / 21$-es, nyitott búvónyílással

1928-ra azonban az Strv m/21 már nem tartozott a korszerű típusok közé. Egyrészt az újabb, fejlettebb külföldi típusok megjelenése, másrészt az egyszerű géppuskánál nagyobb kaliberű, repesz-romboló lövedéket is tüzelni képes, illetve az erődítmények vagy ellenséges páncélosok ellen is hatásos harckocsilöveg hiánya kezdte elavulttá tenni ezt az első világháborús konstrukciót. Utóbbira az Strv $\mathrm{m} / 21$ aktív szolgálata során többször is próbáltak megoldást találni különböző kis kaliberű lövegek beszerelésével, de végül egyetlen ilyen próbálkozás sem zárult elfogadható végeredménnyel.

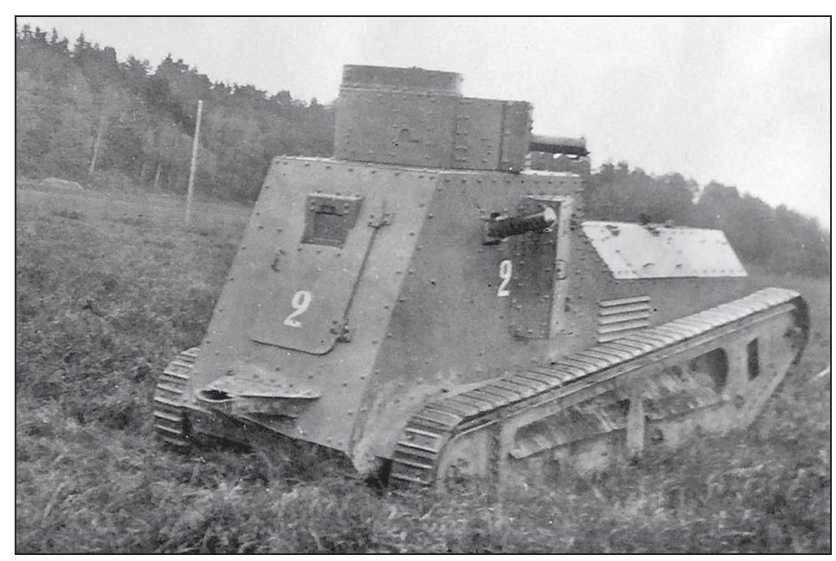

19. ábra. Az LK II / Strv m/21 két oldalán, valamint elöl a vezető mellett és hátul a búvónyíláson/ajtón kialakított, páncélzattal lezárható nyílásokba összesen akár 4 darab további géppuskát is el lehetett helyezni gyalogság elleni másodlagos fegyverzetként. A gyakorlatban általában 1, maximum 2 darabnál többet nem szereltek be, $\mathbf{s}$ gyakran teljesen mellőzték is ezeket a további géppuskákat. A képen a 2-es számú Strv m/21-es látható, oldalsó kiegészítő géppuskával is ellátva

A folyamatos használatból eredő meghibásodások és az amortizáció miatt több példányt is selejtezni kellett. Ezek még használható alkatrészeit „kannibalizálva” üzemeltették tovább a megmaradt Strv m/21-eseket. Egyre sürgősebbé vált tehát egy új típus beszerzése és rendszeresítése.

A svéd hadsereg által kiküldött vizsgálóbizottságok több külföldi páncélos típust is megvizsgáltak, amelyek közül az első világháborús francia Renault FT háború után továbbfejlesztett változata, a Renault NC harckocsi látszott a legígéretesebbnek. Egy próbadarabot meg is vásároltak belőle, ami az Strv fm/28 nevet kapta a svéd kísérletek során. ${ }^{14}$ A próbák során azonban - bár az fegyverzet és páncélvédettség szempontjából felülmúlta az Strv m/21-et -, a francia harckocsit túlságosan megbízhatatlannak, lejtőmászó képességét túl kicsinek, fordulási sugarát pedig túl nagynak találták, és összességében alkalmatlannak ítélték a svéd viszonyok közötti alkalmazásra. Így a svédek a szűk utaknak, hegyes-völgyes terepnek és a hideg skandináv éghajlati viszonyoknak is megfelelő külföldi páncélost nem találva, rövid távon a régi Strv $\mathrm{m} / 21$-ek modernizálása és további hadrendben tartása, illetve hosszú távon egy teljesen új, hazai típus kifejlesztése mellett döntöttek.

20. ábra. A francia Renault NC-27, svéd nevén Strv fm/28 az egyik próbája során, patakba borulva. Svéd kezelői nehezen kormányozható és megbízhatatlan típusnak tartották

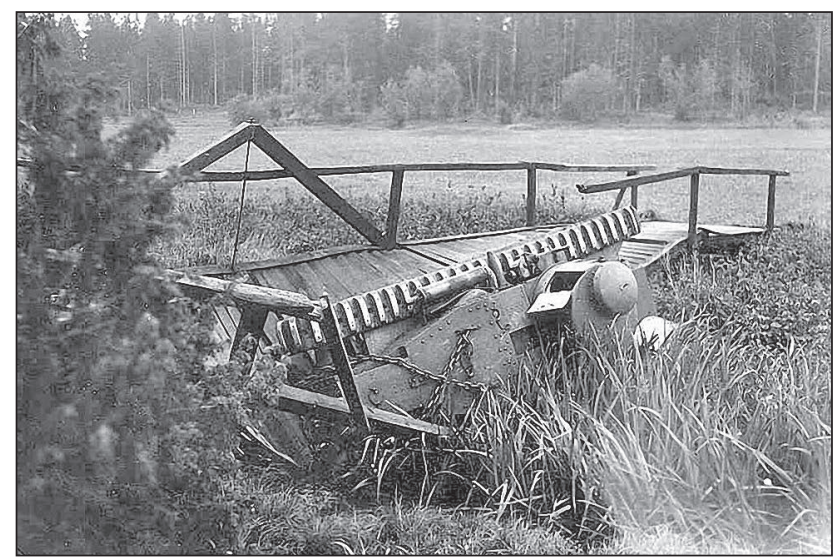




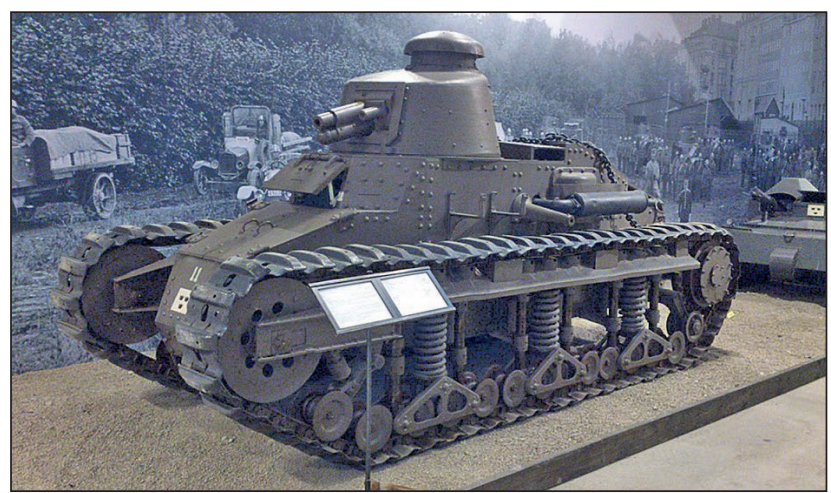

21. ábra. Az Strv fm/28 napjainkban a svéd Arsenalen Tank Museumban

\section{FeJlesztési Kísérletek - A Stridsvagn m/21-29}

1929-ben a mindössze öt megmaradt, működőképes Strv m/21-es egyikén kezdtek hozzá a modernizációs programhoz. Ennek során a harcjármű német motorját egy erősebb, hazai gyártású típusra cserélték, módosították a kipufogórendszerét, továbbá a harckocsit generátorral,

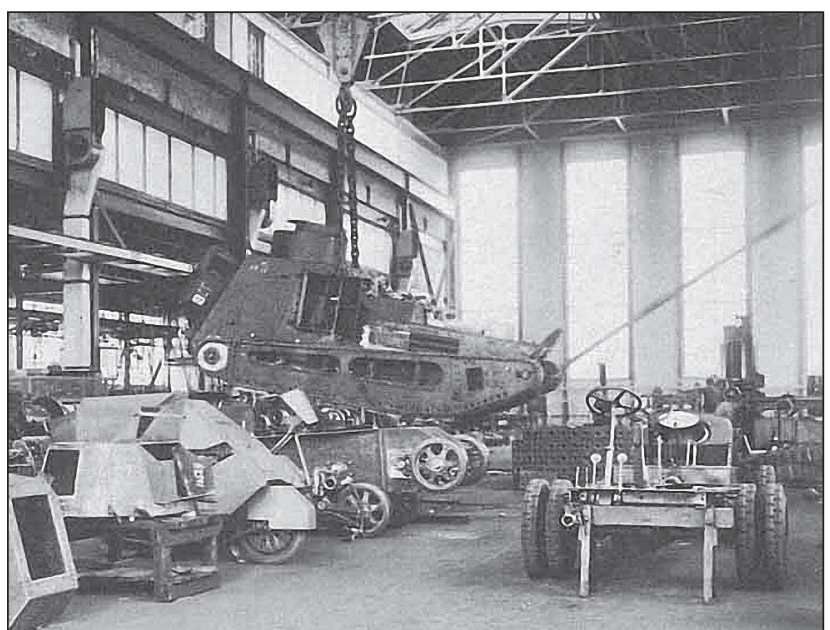

22. ábra. Egy Strv m/21 felújítás közben a Landsverk üzemében, 1934-ben

elektromos indítómotorral, valamint elektromos belső és külső világítással látták el. ${ }^{15} \mathrm{~A}$ páncélzatot nem módosították, mindössze a fő géppuska tornyon kívüli részét látták el

1. táblázat. A Leichter Kampfwagen különböző változatai

\begin{tabular}{|c|c|c|c|c|c|c|}
\hline & \multicolumn{3}{|c|}{ Német Császárság } & \multirow{2}{*}{$\begin{array}{c}\begin{array}{c}\text { Magyar } \\
\text { Királyság }\end{array} \\
\text { LK II } \\
\end{array}$} & \multicolumn{2}{|c|}{ Svéd Királyság } \\
\hline & LK I & LK II (ágyús) & $\begin{array}{c}\text { LK II } \\
\text { (géppuskás) }\end{array}$ & & $\begin{array}{c}\text { Strv m/21 } \\
\text { (fm/21) }\end{array}$ & Strv $\mathrm{m} / 21-29$ \\
\hline Hosszúság & $5485 \mathrm{~mm}$ & $5080 \mathrm{~mm}$ & $5100 \mathrm{~mm}$ & $5100 \mathrm{~mm}$ & $5100 \mathrm{~mm}$ & $5100 \mathrm{~mm}$ \\
\hline Magasság & $2500 \mathrm{~mm}$ & $2675 \mathrm{~mm}$ & $2500 \mathrm{~mm}$ & $2500 \mathrm{~mm}$ & $2500 \mathrm{~mm}$ & $2500 \mathrm{~mm}$ \\
\hline Szélesség & $2005 \mathrm{~mm}$ & $1950 \mathrm{~mm}$ & $1950 \mathrm{~mm}$ & $1950 \mathrm{~mm}$ & $1950 \mathrm{~mm}$ & $1950 \mathrm{~mm}$ \\
\hline $\begin{array}{l}\text { Páncélzat } \\
\text { vastagsága }\end{array}$ & $4-8 \mathrm{~mm}$ & 4-14 mm & 4-14 mm & 4-14 mm & 4-14 mm & 4-14 mm \\
\hline Tömeg & $6,9 \mathrm{t}$ & $8,5 \mathrm{t}$ & $\begin{array}{c}8,75 \mathrm{t} \\
\text { (a jármű } \\
\text { nettó tömege) }\end{array}$ & $\begin{array}{c}\text { 8,75 t } \\
\text { (a jármű } \\
\text { nettó tömege) }\end{array}$ & $\begin{array}{c}\text { 9,7 t } \\
\text { (harci tömeg) }\end{array}$ & $\begin{array}{c}\text { 9,7 t } \\
\text { (harci tömeg) }\end{array}$ \\
\hline Motor típusa & $\begin{array}{c}\text { Daimler Modell } \\
1910, \\
\text { négyhengeres, } \\
\text { benzines }\end{array}$ & $\begin{array}{c}\text { Daimler Modell } \\
1910, \\
\text { négyhengeres, } \\
\text { benzines }\end{array}$ & $\begin{array}{c}\text { Daimler Modell } \\
1910, \\
\text { négyhengeres, } \\
\text { benzines }\end{array}$ & $\begin{array}{c}\text { Daimler Modell } \\
1910, \\
\text { négyhengeres, } \\
\text { benzines }\end{array}$ & $\begin{array}{c}\text { Daimler Modell } \\
1910, \\
\text { négyhengeres, } \\
\text { benzines }\end{array}$ & $\begin{array}{c}\text { Scania-Vabis } \\
1554, \\
\text { négyhengeres, } \\
\text { benzines }\end{array}$ \\
\hline Teljesítmény & 55-60 LE & $55-60$ LE & 55-60 LE & 55-60 LE & $55-60 \mathrm{LE}$ & 85 LE \\
\hline $\begin{array}{l}\text { Végsebesség } \\
\text { úton }\end{array}$ & $18 \mathrm{~km} / \mathrm{h}$ & $16 \mathrm{~km} / \mathrm{h}$ & $16 \mathrm{~km} / \mathrm{h}$ & $16 \mathrm{~km} / \mathrm{h}$ & $16 \mathrm{~km} / \mathrm{h}$ & $18 \mathrm{~km} / \mathrm{h}$ \\
\hline Fő fegyverzet & $\begin{array}{c}7,92 \text { mm } \\
\text { MG } 08 \\
\text { géppuska }\end{array}$ & $\begin{array}{c}57 \mathrm{~mm} \\
\text { Maxim- } \\
\text { Nordenfelt } \\
\text { ágyú, } \\
\text { később } 37 \mathrm{~mm} \\
\text { Krupp löveg } \\
\end{array}$ & $\begin{array}{c}\text { 7,92 mm } \\
\text { MG } 08 \\
\text { géppuska }\end{array}$ & $\begin{array}{c}8 \text { mm 07/12M. } \\
\text { Schwarzlose } \\
\text { géppuska }\end{array}$ & $\begin{array}{c}6,5 \mathrm{~mm} \\
\text { Ksp m/14 } \\
\text { géppuska }{ }^{19} \\
\text { vagy } 6,5 \mathrm{~mm} \\
\text { Ksp m/14-29 } \\
\text { géppuska }{ }^{20} \\
\end{array}$ & $\begin{array}{c}6,5 \text { mm } \\
\text { Ksp m/14-29 } \\
\text { géppuska }\end{array}$ \\
\hline $\begin{array}{l}\text { Legénység } \\
\text { létszáma }^{21}\end{array}$ & 2-3 fő & 2-3 fő & 2-4 fő & 4 fő & 2-4 fő & 3-4 fö \\
\hline Példányszám & $1 \mathrm{db}$ & $1 \mathrm{db}$ & $\begin{array}{l}\text { bizonyítha- } \\
\text { tóan legalább } \\
39 \mathrm{db} \\
\text { összeállításá- } \\
\text { hoz elegendő } \\
\text { alkatrész }\end{array}$ & $\begin{array}{c}14 \text { db (ezekből } \\
\text { végül } \\
\text { használatba } \\
\text { véve } 6 \mathrm{db} \text { ) }\end{array}$ & $10 \mathrm{db}$ & $\begin{array}{c}5 \text { db } \\
\text { (Strv m/21- } \\
\text { esekből } \\
\text { átépítve) }\end{array}$ \\
\hline
\end{tabular}



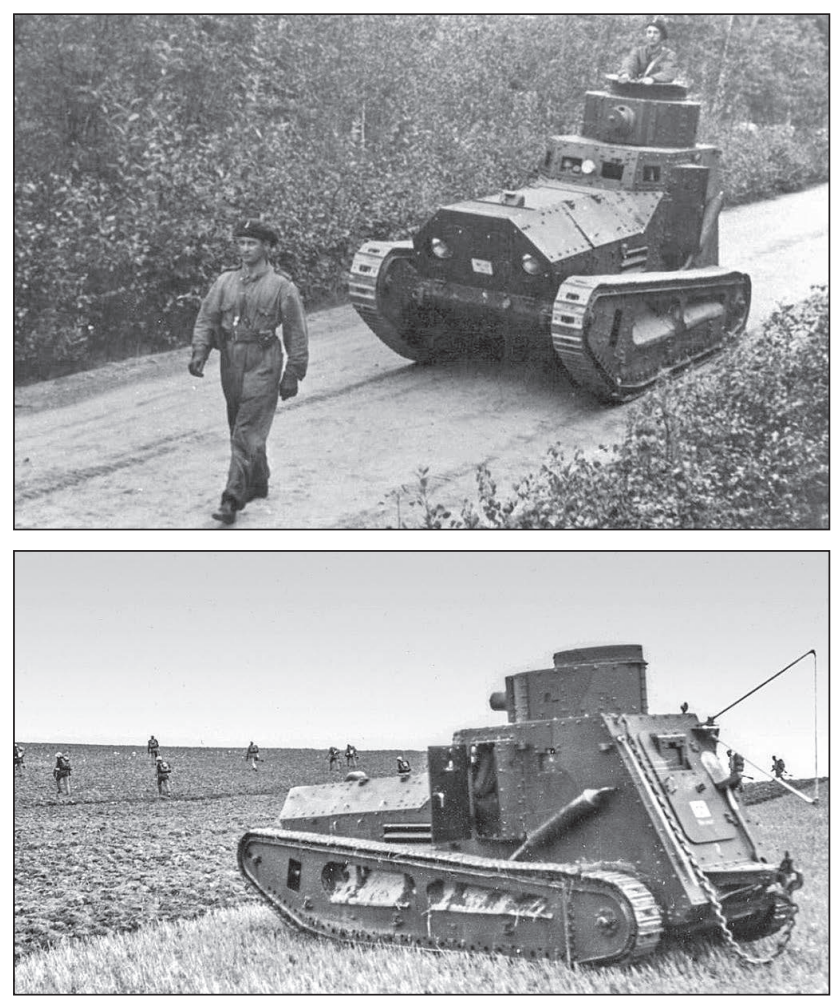

23. ábra. Az Strv m/21-29 menet közben és egy 1935-ös hadgyakorlaton. A képeken jól látszanak a korábbi változathoz képest új, az orr-részen vágott, páncéllal lezárható nyílásba helyezett fényszórók, a fö géppuska új páncélborítása, az új antenna és a módosított kipufogó

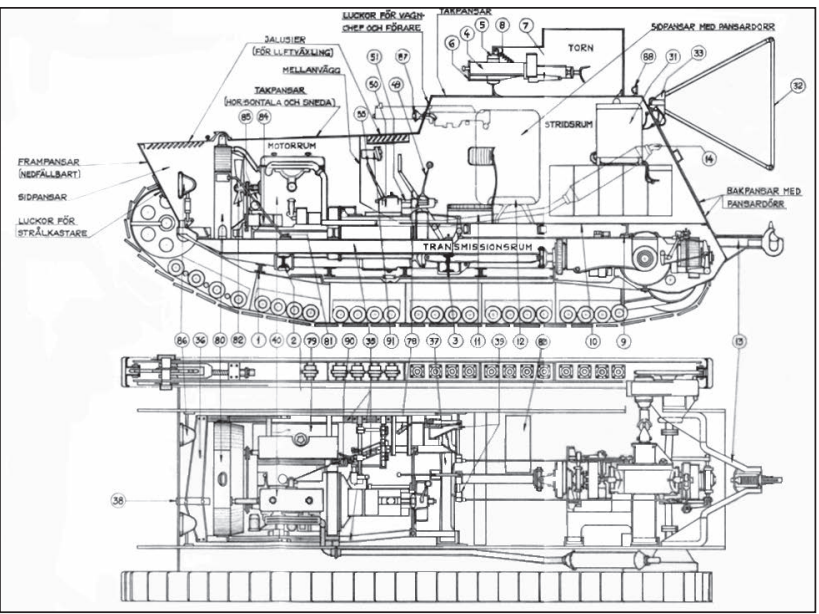

24. ábra. Az Strv m/21-29 korabeli metszete

gömbcsuklós páncélburkolattal. Ezeken kívül a járművet nagyobb teljesítményű rádióadó-vevővel és összecsukható, háromszög alakú antennával is ellátták. A végeredmény elnyerte a svéd hadvezetés tetszését, így a maradék négy járművet ugyanilyen módon a Nydqvist och Holm AB és a Landsverk AB vállalatok újították fel 1929-1934 között. ${ }^{16}$ Az Strv $\mathrm{m} / 21$ modernizált változata a Stridsvagn $\mathrm{m} / 21-29$ nevet kapta. ${ }^{17}$

A felújítási munkálatokkal egy időben ismét történtek kísérletek a tǔzerő növelésére is. Az egy darab géppuskából álló fegyverzetet egy 37 mm-es Škoda gyártmányú lövegre cserélték, de a gyakorlati próbák alapján a löveg hátrasiklása túlságosan megterhelő volt az LK II-től örökölt torony-
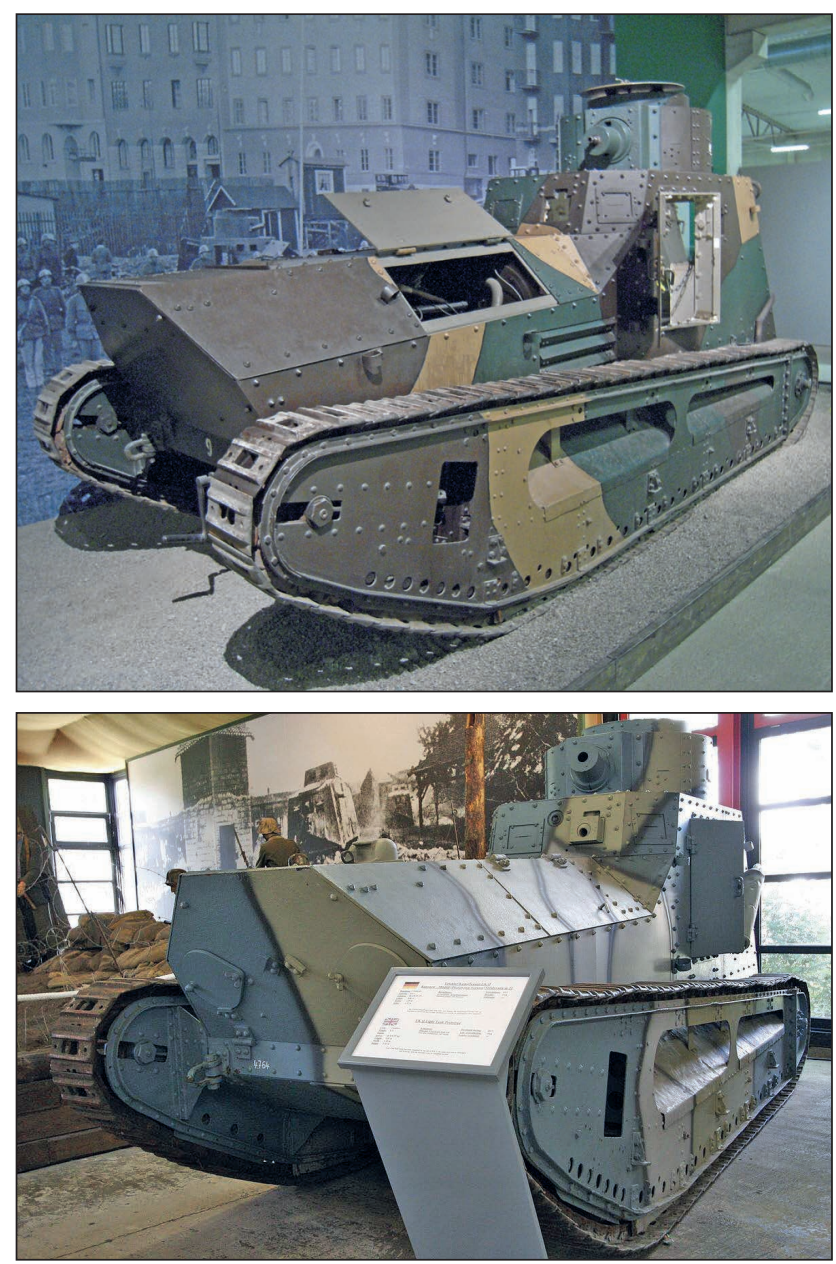

25. ábra. Az Strv m/21 és Strv m/21-29 egy-egy múzeumi példánya napjainkban

nak és toronygyűrűnek, így végül feladták az erre irányuló terveket.

Az Strv m/21-29 kísérleti és oktatójárműként végül 1938ig állt szolgálatban, egészen az új, teljes értékű páncélos, az Strv m/38 könnyü harckocsi ${ }^{18}$ hadrendbe állításáig. Ezt követően az eredeti 10 példány üzemképtelen darabjainak többsége tüzérségi céltárgyként fejezte be a pályafutását, egy Strv m/21 pedig visszatért az LK II szülőhazájába, amikor azt egy németországi múzeumnak ajándékozták. Ez utóbbi példány azonban a nem sokkal később kezdődő második világháború során eltűnt, minden bizonnyal megsemmisült.

Mára összesen négy példány maradt fenn ebből a típusból: egy darab eredeti Strv $m / 21$ és két darab modernizált Strv m/21-29 a svédországi Arsenalen Tank Museumban, valamint további egy darab Strv m/21-29 a németországi Munsterben található Deutsches Panzermuseumban.

\section{FELHASZNÁLT IRODALOM}

Baadstöe, Christer: How the Swedish Armoured Corps was born https://www.sphf.se/svenskt-pansar/historia/ how-the-swedish-armoured-corps-was-born/ (Utolsó megtekintés: 2018.10.11.);

Blomster, Karl és Norlund, Viktor levéltári gyűjteményei; Bartholomew, E.: First World War Tanks. Shire

Publications, Bucks (1986). 22-23. o.; 
Bíró Ádám - Éder Miklós - Sárhidai Gyula: A Magyar Királyi Honvédég külföldi gyártású páncélos harcjárművei 1920-1945. Petit Real, Budapest, 2006. 9., 16. o.;

Bíró Ádám - Sárhidai Gyula: A Magyar Királyi Honvédég hazai gyártású páncélos harcjárművei 1914-1945. Petit Real, Budapest, 2012. 40-45. o.;

Bíró Ádám: A páncélos fegyvernem megteremtésének kezdetei a Magyar Királyi Honvédségben - az LK-II és a FIAT 3000 B. In.: Haditechnika, 1993/3. 61-65. o.;

Bombay László - Gyarmati József - Turcsányi Károly: Harckocsik 1916-tól napjainkig. Zrínyi, Budapest, 1999. 40-44., 51-52., 58., 60. o.;

Bonhardt Attila - Pánczél Mátyás - Végh Ferenc - Szekeres József - Hattyár István - Sári Szabolcs: A magyar páncélosalakulatok története. Zrínyi, Budapest, 2015. 42-54. o.;

Bonhardt Attila - Sárhidai Gyula - Winkler László: A Magyar Királyi Honvédség fegyverzete. Zrínyi, Budapest 1995. 13-15., 48. o.;

Éder Miklós: Az LK-II. német könnyűharckocsi magyar szolgálatban. In: Militaria Modell 1992/2. 12-13. o.;

Edwards, Robert J.: Panzers Forward - A Photo History of German Armor in World War II. Stackpole Books, Lanham MD, 2018. 2. o.;

Fleischer, Wolfgang: Military Vehicles of the Reichswehr. Schiffer Publishing, Atgen PA, 1996. 3. o.;

Haupt, Werner: A History of the Panzer Troops 19161945. Schiffer Publishing, Atgen PA, 1990. 15. o.;

Janson, O.: The Swedish machineguns before 1950. http://www.gotavapen.se/gota/artiklar/utv_ksp58/ ksp14/2_ksp14.htm (Utolsó megtekintés: 2018.09.01.);

Jones, Ralph E. - Rarey, George H. - Icks, Robert J.: The Fighting Tanks since 1916. The National Service Publishing, Washington D.C., 1933. 139-140. o.;

Lindström, Rickard O.: Strv m/21. http://www.ointres.se/ strv_m_21.htm (Utolsó megtekintés: 2018.10.11.);
Lindström, Rickard O.: Strv Renault FT17 \& NC27. http:// www.ointres.se/strv_renault.htm (Utolsó megtekintés: 2018.10.11.);

Moore, Craig: Tank Hunter - World War One. The History Press, Gloucestershire, 2017. 65-68.;

Mujzer Péter: A magyar páncélos fegyvernem kezdetei. I. rész. In: Haditechnika 2016/1. 3-4. o.;

Пашолок, Юрий (Pasolok, Jurij): Первый танк шведской армии. https://warspot.ru/8156-pervyy-tankshvedskoy-armii (Utolsó megtekintés: 2018.10.11.);

Пашолок, Юрий (Pasolok, Jurij): С прицелом на экспорт. https://warspot.ru/5917-s-pritselom-naeksport Az eredetileg orosz nyelven megjelent cikk angol fordítása: http://tankarchives.blogspot. com/2017/05/renault-nc-destined-for-export.html (Utolsó megtekintés: 2018.10.11.);

Пашолок, Юрий (Pasolok, Jurij): Трудный выбор шведской армии. https://warspot.ru/8916-trudnyyvybor-shvedskoy-armii $A z$ eredetileg orosz nyelven megjelent cikk angol fordítása: http://tankarchives. blogspot.com/2017/11/the-swedish-armys-toughchoice.html (Utolsó megtekintés: 2018.10.11.);

Poór István (főszerk.): Harckocsi típuskönyv. Zrínyi, Budapest, 1980. 202. o.;

Schneider, Wolfgang - Strasheim, Rainer: German Tanks in World War I - The A7V and Early Tank Development. Schiffer Publishing, West Chester PA, 1990. 42-46. o.;

Varga A. József (szerk.): Magyar autógyárak katonai járművei. Maróti, Budapest, 2008. 61-62., 203-205. o.;

White, Brian Terence: German Tanks \& Armored Vehicles 1914-1945. Arco, New York, 1968. 26-27. o.;

White, Brian Terence: Tanks and Other Armoured Vehicles 1900-1918. Blandford Press, London, 1970. 170-171., 182-183. o.;

Zaloga, Steven J.: German Panzers 1914-18 (New Vanguard 127). Osprey, Oxford, 2006. 7-9., 12., 41-42. o.

\section{JEGYZETEK}

8 Kungliga Arméförvaltningens Artilleridepartement, magyarul a svéd Királyi Hadseregigazgatás Tüzér Osztálya. Az első világháború új fegyvereinek, köztük a harckocsinak a véleményezésével, illetve a lehetőség szerinti vizsgálatával, kipróbálásával is megbízott svéd katonai szerv.

9 Annak kiderítése további kutatásokat kívánna, hogy hogyan és miként is kerülhettek a háborút követő kaotikus időszakban ezek a titkos hadifegyverek polgári cégek kezébe - már ha valóban történt tulajdonosváltás, és nem pusztán közvetítőként használta ezeket a kisebb német cégeket a német állam, a hadsereg, vagy a hadianyagokat gyártó valamelyik nagyvállalat.

10 Így, a korábban, 1920-ban Magyarországra leszállított 14 darab, az 1921-ben még a Steffen \& Heymann GmbH birtokában lévő 15 darab és a Wilhelm Ugé GmbH további 10 darabjával együtt összesen legalább 39 darab legyártott LK II-es létezése bizonyítható, amelyek javarészét feltehetően akár már az antant - német fegyverszünet megkötése után gyártották vagy szerelték össze. A Steffen \& Heymann által a svédeknek küldött fényképeket és a végül Svédországban megépült, a Wilhelm Ugé-tól származó harcjárművekről készült fényképfelvételeket összehasonlítva, a járműveken felfedezhető apróbb, gyártási megoldásokból fakadó különbségek alapján a svéd kutatók arra a következtetésre jutottak, hogy különböző példányokról volt szó, és a két cég kétséget kizáróan nem ugyanazokat a konkrét páncélosokat kínálta eladásra.

11 A korabeli tudósítások, újságcikkek és a későbbi szakirodalom feltételezhetően azért számolt be svédországi gyártásról, mert a svéd katonai és politikai vezetők ezzel a féligazsággal, álhírrel igyekeztek leplezni az LK II-k vásárlásával kapcsolatos zavaros körülményeket, és, hogy elkerüljék a potenciális nemzetközi botrányt amiatt, hogy nemzetközi jogot sértve a vesztes Németországtól tiltott hadieszközöket vásároltak. Sokkal „szalonképesebb” volt úgy nyilvánosságra hozni a svéd harckocsik létrejöttét, mint hogyha a svédek csupán a terveket vásárolták volna meg ami amúgy legális lett volna -, és a harckocsikat már eleve Svédországban hozták volna létre, hazai nyersanyagokból.

12 A típus több névváltoztatáson is átesett szolgálata során. Első hivatalos elnevezése az átadás évét jelölve Pansarvagn försöksmodell 1922, röviden fm/22 lett, ami magyarul annyit jelent, hogy „Páncélkocsi kísérleti modell 1922”. Ezt 1924-ben Bertil Burén, a svéd páncélos alakulatok főparancsnokának kezdeményezésére módosították Stridsvagn („harckocsi”) modell 1921, vagy röviden Strv m/21-re, követve a tankok elnevezésére ekkorra már bevett svéd szó alkalmazását és a jelölve az elméleti hadrendbe álítás évét. 1927-ben, amikorra e típusra már elavulófélben lévő, élvonalban már be nem vethető típusként tekintettek, nevében is visszaminősítették azt kísérleti harckocsinak, vagyis a típus neve ekkortól kezdve Strv fm/21 lett. Az 1930-as évek elején felújított, kis mértékben továbbfejlesztett változat neve a modernizációs program kezdő évének megjelölésével Stridsvagn m/21-29 lett. A félreértések elkerülése végett a cikkben az 1921-1929 közötti időszakra csak az Strv $m / 21$ elnevezést használom.

131923 őszén a svédek kipróbálásra megvásároltak a franciáktól egy darab Berliet típusú toronnyal és 37 mm-es Puteaux SA18 löveggel szerelt, használt Renault FT-t. Más források azt feltételezik, hogy a vásárlásra már korábban, 1921-ben sor került. Mindenesetre a próbák után a svédek elégedetlenek voltak a típus menettulajdonságaival és az Strv m/21-ekéhez képest alacsony végsebességével, így további darabokra nem tartottak igényt. Ennek az egyetlen, megbízhatatlansága miatt kezelői által „Putte” (magyarul kb. „Kiábrándító”) becenévre keresztelt FT-nek a 
37 mm-es lövegét eltávolították és 1924-ben megpróbálták beszerelni az egyik Strv m/21-esbe, sikertelenül. A „Putte” végül a fegyverzetét soha nem kapta vissza, és mint tüzérségi célpont került megsemmisítésre 1927-ben.

14 A svédek a Renault NC korai, spirálrugós-himbaszerkezetes, kis görgős felfüggesztéssel szerelt Renault NC1, vagy Renault Modèle 26/27 gyári nevű változatból vásároltak egy próbadarabot, amelyet - miután megbukott a franciaországi teszteken -, a Renault cég NC-27 néven kezdett el exportra felkínálni.

15 Ezt megelőzően az LK II-ket / Strv m/21-eket csak a járművön kívülről, kurblizással lehetett beindítani, és a külső-belső világításról olajlámpáknak kellett gondoskodniuk.

16 Az hosszú évekig elhúzódó felújításnak elsősorban a Svédországba begyűrűző nagy gazdasági világválság, és annak következményeként a svéd hadsereg nagyon is szűkös költségvetése volt az oka.

17 Érdekesség, hogy többek között Heinz Guderian, a második világháborús stratéga és a német páncélos hadviselés egyik közismert teoretikusa életében először vezetett harckocsija is egy ilyen svéd m/21-29 volt, amelyet egy, a német hadseregnek Svédországban rendezett bemutató alkalmával próbálhatott ki 1929-ben.

18 A magyar 38M Toldi könnyű harckocsi alapjául is szolgáló Landsverk L-60 svéd igények szerint módosított változata.

19 6,5 mm kaliberű, vízhűtéses Kulspruta m/1914 géppuska, az osztrák-magyar M.07/12 Schwarzlose géppuska Svédországban, licenc alatt gyártott változata. Idővel az összes Strv m/21 tornyában elhelyezett Ksp m/14 géppuskát a frissen hadrendbe állított Ksp m/14-29 géppuskára cserélték le. Az Strv m/21 egy példányán a géppuskát egy $37 \mathrm{~mm}$-es Puteaux lövegre cserélték, majd az azzal végzett, végül sikertelen kísérletek után a kísérleti járművet ismét géppuskával fegyverzeték fel. Később, szintén ideiglenesen egy másik példányon egy 37 mm-es Škoda löveget próbáltak ki, de a kísérletek ezzel sem zárultak sikeresen.

20 6,5 mm-es Kulspruta m/14-29, az amerikai Browning M1917 vízhűtéses géppuska Svédországban gyártott, enyhén módosított változata.

$21 \mathrm{Az}$ LK II / Strv m/21 minimális kezelőszemélyzete két fő, egy harckocsiparancsnok, aki az egy főre tervezett forgótoronyban kapott helyet (s a fő fegyverzetet is kezelte), illetve egy, a harckocsitestben helyet kapó vezető/gépész volt. Mindazonáltal, a viszonylag tágasnak mondható küzdőtérben további két főnek volt még elegendő hely, akik vagy a parancsnok és vezető munkájában segédkeztek, vagy az esetlegesen beszerelt további géppuskákat vagy rádiót kezelték. Általánosságban a németek és a svédek 3 fős személyzetet alkalmaztak. Korabeli fényképfelvételek tanúsága szerint a Magyarországon kiképzésre használt LK II-k kezelőszemélyzete 4 fő volt.

\section{Buga László - Hegediús Ábel - Jankó Annamária - Mihalik József - Rojkó Annamária - Suba János - Szabó Béla - Szabó Gyula - Szabóné Szalánczi Erika - Tremmel Ágoston - Várszegi Lajos}

\section{A magyar katonai térképészet 100 éve 1919-2019}

Bár a magyar katonai térképészet gyökerei egészen az 1700-as évek közepéig nyúlnak vissza, mégis 1919. február 4-e az önálló magyar katonai térképészet születésnapja, ekkor alakult meg a Magyar Katonai Térképező Csoport. A 100. évfordulót - többek között - egy monumentális, 484 oldalas album megjelentetésével ünnepelték meg. Az impozáns kötet katonatérképészeink mindenkor magas szakmai színvonalú és elkötelezett munkájának állít emléket.

A közel ötszáz oldalas könyvet öt fejezetre osztották, amelyek a kezdetektől egészen napjainkig mutatják be a magyar katonai térképészet különböző korszakait. A könyvben 42 egész oldalas illusztrált térképrészlet, 41 táblázat és 335 kép, valamint fotórészlet található. A könyvhöz mellékelt DVD-n azokból a katonai topográfiai és tematikus térképekből, illetve a nagyközönség számára készült térképekből látható igényes válogatás, amelyek az elmúlt száz év során a Térképészeti Intézetnél készültek. A könyv bemutatja a katonai térképészet szervezetének változásait, a műszaki technológiai fejlődést, és végigköveti az évek során született nagy térképészeti vállalkozásokat, eredményeket is.

A katonatérképészek munkája ugyanis a kezdetektől napjainkig a katonai felmérések

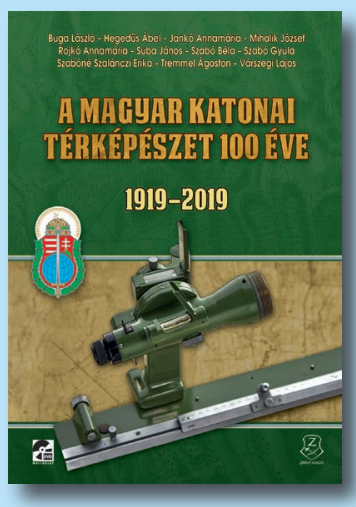
története. A XVIII. század elején a hadviselésben megjelenő új taktika és stratégia a hadseregek nagyobb mozgékonyságát igényelte, és megkövetelte a terephez való jobb alkalmazkodási képességet. $A$ hadszíntér nagymértékben kiszélesedett, ez is fokozta a térképigényt. A hadtudomány fontos elemévé vált a katonai térképészet. A Habsburg Birodalom első katonai felmérése Magyarországon 1766-ban kezdődött és 19 évi munkával készült el, 1:28 800 méretarányban. Ezt a felmérést még három követte a Monarchia felbomlásáig. A két világháború alatt a katonai térképészek megfeszített munkával dolgoztak, majd a XX. század második felét gyorsuló ütemű műszaki technológiai fejlődés jellemezte. A technológiai korszakváltással, a digitális térképészet megjelenésével egy időben politikai rendszerváltás is történt. Végül megismerkedhetünk a katonai térképészet mai, NATO-csatlakozás utáni helyzetével.

A könyv bemutatóján Szalay László ezredes, az MH Geoinformációs Szolgálat szolgálatfőnöke a következő szavakkal ajánlotta a könyvet: „A százéves évforduló olyan történelmi pillanat, melynek alkalmával illo és kötelesség is megemlékezni az elődeinkről. Ez a könyv megjelenését, formáját és tartalmát tekintve méltó emléket álít a magyar katonatérképészek nemzedékeinek, az általuk végzett nagyjelentőségű munkának, amellyel mindenkor biztosították a magyar haderő és a haza védelméhez szükséges térképészeti támogatást, végrehajtották az ország térképellátása érdekében rájuk hárult feladatokat" - hangsúlyozta az ezredes. Végezetül köszönetét fejezte ki mindazoknak, akik részt vettek e könyv elkészítésében.

A 484 oldalas, füzött, keménytáblás, impozáns kötet 7800 Ft-os áron kapható a könyvesboltokban, illetve közvetlenül a Zrínyi Kiadónál is, 25\%-os helyszíni kedvezménnyel (1087 Budapest, Kerepesi út 29/b. Tel.: 06 1-459-5373, e-mail: gyoredina@armedia.hu), továbbá megrendelhető a kiadó online felületén: http://www.hmzrinyi.hu/termek/a_magyar_katonai_terkepeszet_100_eve_1919_2019. (SzA) 